\title{
A SYRIAC CODEX FROM NEAR PALMYRA AND THE 'GHASSANID' ABOKARIB
}

\author{
FERGUS MILLAR \\ ORIENTAL INSTITUTE, OXFORD
}

\begin{abstract}
This paper concerns a Syriac codex copied near Palmyra in the midsixth century, whose colophon, printed and translated, refers to the 'monophysite' bishops, Jacob and Theodore, and to 'King' Abokarib. It explores the evidence for the spread of the use of Syriac in the provinces of Phoenicia Libanensis and Arabia, and the implications of the reference to Abokarib, questioning whether 'Ghassanid' is an appropriate term for the family to which be belonged.
\end{abstract}

\section{INTRODUCTION}

This paper takes as its primary topic a Syriac codex containing a translation of some of John Chrysostom's homilies on the Gospel of Matthew which was copied in a monastery near Palmyra in the middle decades of the sixth century, and discusses the political and religious context which is revealed in a note by the scribe at the end. This colophon, printed by Wright in his great Catalogue of Syriac manuscripts in the British Museum, published in 1870-2, seems never to have been re-printed since, and is reproduced below along with an English translation. 
In the wider perspective which needs to be sketched out first, the codex is very significant for the history of language-use in the Late Roman Near East, for it is a very rare item of evidence for the writing of Syriac in the Palmyrene region. As we will see below, there is also some, if only slight, evidence for the use of Syriac further south in the province of Phoenicia Libanensis, namely in the area of Damascus, and also in the Late Roman province of 'Arabia'.

\section{THE ORIGIN AND EXPANSION OF THE USE OF SYRIAC}

As is well known, the particular dialect and script of Aramaic which is identified as 'Syriac' emerged in the course of the first to fourth centuries CE in the broad zone from the Euphrates to the Tigris, the area of which most, after the Roman conquest of the 190s, became the provinces of Osrhoene and Mesopotamia. Whether we should attribute the evolution of Syriac as a Christian language of culture specifically to Edessa (as opposed, for instance, to Nisibis, from which Ephrem came, or to the area further east, where Aphrahat wrote) is more uncertain; ${ }^{1}$ but this problem need not concern us here. What is clear from the evidence both of inscriptions and of manuscripts is that the use of Syriac as a language of Christian literature and public life spread westwards, across the Euphrates, into the Late Roman provinces of Euphratensis and of Syria I and II only in the course of the fifth century, and above all in the sixth. ${ }^{2}$ It is entirely in keeping with this general pattern that a newly-discovered mosaic inscription in Syriac should have been found in the Jarablus area, on the right bank of the Euphrates; it dates, as it seems, to CE 406/7.3

Syriac inscriptions were subsequently put up, and Syriac codices were copied, in the area between the Euphrates and Antioch, in the Syrian steppe, in the Limestone Massif, and as far south as the region of Apamea. It is noteworthy that the Syriac translation of a selection from the Greek Acta of the Second Council of Ephesos

1 Millar 2011.

2 For inscriptions see Briquel Chatonnet, Debié and Desreumaux 2004; Millar 2009b, p. 51-52; Brock 2009; Briquel Chatonnet, F. and Desreumaux, A. 2011a. For the geographical and chronological distribution of the copying of Syriac codices see Mundell Mango, 1991, and Millar 2009a, p. 52-54.

${ }^{3}$ Briquel Chatonnet, F. and Desreumaux, A. 2011b. 
of CE 449, designed to support the monophysite case, was copied by a scribe who came from Antioch, working in a monastery near Apamea in CE 535. ${ }^{4}$ But further south, in the Bekaa valley, and on the Mediterranean coast, from Seleucia down to the territory of Tyre in Phoenicia, it does not seem that as yet we have any evidence either for the copying of texts or for the putting-up of inscriptions in Syriac.

\section{SYRIAC AND CHRISTIAN PALESTINIAN ARAMAIC IN CONTACT?}

At the southern end of the province of Phoenicia (Maritima), and in Palaestina I and II, we encounter a quite different linguistic pattern: Greek, as everywhere, remains in use, but abundant evidence testifies to Jewish literary composition in Hebrew and Aramaic, and to the use by Jews of the square Hebrew alphabet for inscriptions in both Hebrew and Aramaic. But we also see the emergence, apparently around CE 400, of a new form of the distinctive Samaritan script. ${ }^{5}$ At about the same time we also see the appearance of a distinctive script used by Christians, sometimes labelled 'Christian Palestinian Aramaic' (CPA), but in fact found in southern Phoenicia, in the area near Ptolemais; in Palaestina I and II; and in the province which the Empire now designated as 'Arabia', covering the southern part of modern Syria, south of Damascus, and the northern part of modern Jordan. ${ }^{6}$

Most of those examples of CPA which come from Arabia derive from the southern half of the province, namely that part of the plateau which stretched from Umm al-Rasas to near Gadara (which itself lay within Palaestina II). But two of them come from some $50 \mathrm{~km}$ further north, at Dayr Adas and Dayr Makir, thus correcting any assumption that the use of CPA was confined to the southern part of the province. ${ }^{7}$ These two documents are however of wider importance, for they serve to raise the question of Christian linguistic usage in the inland area which stretches north

${ }_{4}$ Millar 2009a, with a plate on p. 50 showing the first of two attestations by the scribe of BL Add. 14,530, and a translation of it on pp. $56-7$.

${ }^{5}$ See the remarkable paper by the late Dan Barag 2010.

6 See Hoyland 2010, with an inventory of Christian Palestinian Aramaic texts and a map of their distribution, on p. 37-39.

${ }^{7}$ So, erroneously, Millar 2009b, p. 103, n. 32. 
from Arabia into Phoenicia Libanensis. The metropolis of this latter, and very little-known, Late Roman province was Damascus, and the border with Arabia lay not far to the south of the city, though exactly where is not known - and perhaps does not matter much, since, as we will see, there are reasons to think of those two provincial areas as showing a significant degree of unity in both linguistic and ecclesiastical terms. Phoenicia Libanensis stretched as far as Emesa in the north west, in the upper Orontes valley, and to Palmyra in the north east, along the frontier road, the Strata Diocletiana, which linked it to Damascus.

The problem of Christian language-usage in the sixth century in Arabia-and, as it now seems clear, in Phoenicia Libanensis also-is raised in vivid and detailed form by the letter written from Arabia in CE $569 / 70$ by a large number of monophysite Archimandrites and other monks, and addressed to a group of bishops in Constantinople. This letter forms one item in a dossier of monophysite documents (almost all of which are also letters) which date between the 530s and the 580s, and are contained in a codex which was copied not long after, perhaps around CE 600.8 The entire collection as it stands is in Syriac, but it is stated explicitly at one point that the relevant text had been translated from Greek; and is quite clear anyway that the vast majority of the documents, and possibly all of them, will initially have been written in Greek. So, between the original composition of each letter, on the one hand, and the Syriac codex on the other, lie three distinct processes: assembling the collection, translating the documents, and copying them into a single codex. In the vast majority of the material there is no indication of any part played by Syriac at the moment of initial composition; and this must certainly be true of the text of the letter of the Archimandrites itself.

What makes this letter distinctive, and puzzling in terms of linguistic usage, is the list of 137 personal subscriptions by Archimandrites and monks which is attached to it. These too might in principle also have been originally in Greek, and then have been translated for inclusion in the Syriac dossier. But in fact this cannot be so, for in the case of 20 of them, but only 20 out of 137 , it is explicitly stated that the original had been in Greek. It will be worth

8 BL Add. 14,602, see Wright 1871, vol. II, no. DCCLIV, 701-715, published by Chabot 1907, p. 209-224, with Latin translation in Chabot 1933, p. 145-156. See also van Roey and Allen 1994. 
reproducing the heading and the first four subscriptions, of which the second is one of those which had originally been in Greek, followed by a translation:

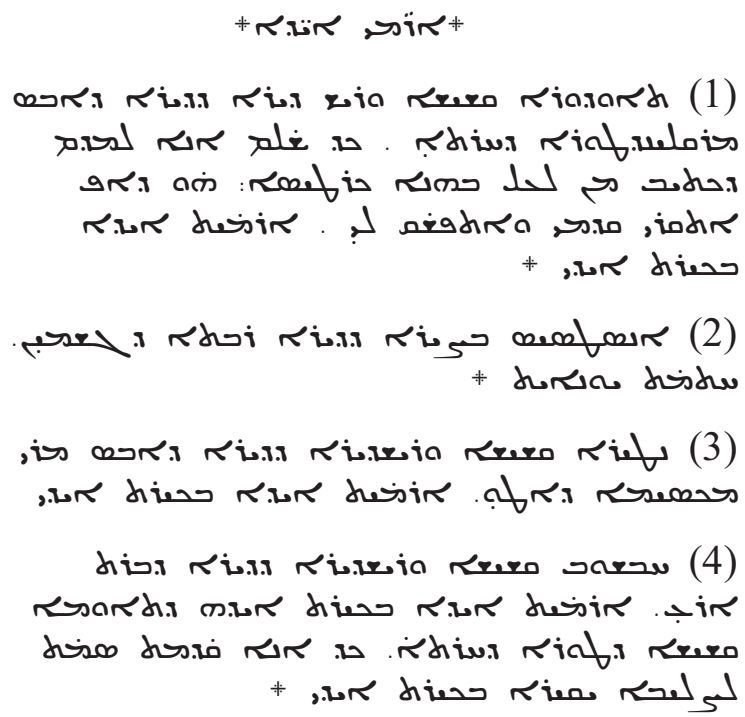

Those subscribing (literally 'placing the hands')

(1) I, Theodoros, presbyter and head of the monastery (RYŠ DYR') of the monastery of Abbas Markellinos of the mountain of HRT', since I approve whatever is written above in this document, which was also read before me and translated for me, I have subscribed with my own hand.

(2) I, Anastasios, an insignificant (member) of the great monastery of GŠMYN, have signed in Greek (HTMT YWN'YT).

(3) I, Netira, presbyter and head of monastery of the monastery of Abbas Mar Maximos in 'TW, have signed with my own hand.

(4) I, Habshub, presbyter and head of monastery of the monastery of BRT 'R', have signed by the hand of Thomas, presbyter of the mountain of HRT', after I had previously put a sign of the precious Cross with my own hand. 
As will be obvious from what is said above, these subscriptions are not in themselves evidence for writing as practised in Arabia, since they come from a subsequent copy, of which the place of writing is not known. But the list as a whole indicates unambiguously that 117 of the 137 original subscriptions had not been written in Greek. So what can we deduce about the language or script in which the individuals concerned had entered their names in their own handwriting? And what geographical area is reflected in this list?

To take the latter question first, I earlier argued firmly, in setting out the background and translating the whole list, that when the Archimandrites described themselves as coming from 'the province of Arabia' (DMN HWPRK' D'RBY') they must be understood to have given these terms their natural contemporary meaning, namely the Roman province. ${ }^{9}$ But in an article which was published along with that one, Robert Hoyland demonstrated that the names of the localities by which the monasteries listed are identified show that in reality the list includes several which lie close to Damascus, and thus must have come within the province of Phoenicia Libanensis. ${ }^{10}$ In particular, Darayye, which is mentioned 11 times in all, must be the modern Dārayyā, some 10 $\mathrm{km} \mathrm{SW}$ of Damascus. Moreover, there is a strong possibility that the location described in subscription no. 119 as HLYWRM should be identified with the place listed as 'Heliaramia' by the Tabula Peutingeriana, lying to the west of Palmyra, and 'Heliaramia' in its turn with Qasr al-Hayr al-Gharbi, the site of a famous Ummayad palace, where the archaeological remains include sixth-century Greek inscriptions from a monastery, two of which mention the 'Ghassanid' Arethas as phylarchos or patrikios (see further below). ${ }^{11}$ If that identification is correct, then the area from which the Archimandrites came was even wider, and was not confined to Arabia or to the zone immediately to the north of the Arabia/Phoenicia Libanensis border. But, as we will see, there is evidence to suggest that the Palmyra area also had significant features in common with southern Libanensis and Arabia.

As regards the other question, since 20 of the 137 subscriptions are recorded as having been written originally in

\footnotetext{
${ }^{9}$ Millar 2009b.

${ }^{10}$ Hoyland 2009, see map on p. 129.

${ }^{11}$ See Genequand 2006.
} 
Greek, and nothing is said about the original language of the others, it is natural to presume that all the others had been in Syriac, and that (as we should suppose) the writers had used the distinctive Syriac script. However, the two inscriptions in CPA mentioned above should make us pause. For both Dayr Makir and Dayr Adas, where these inscriptions were found, belong precisely in the main zone where the authentically 'Arabian' monasteries of the letter of CE 569/70 were located; ${ }^{12}$ and Makir (MKR) itself appears three times in the list (subscriptions $11 ; 65 ; 73$ ). So, is it possible that the language and script in which some at least of the Archimandrites had originally given their hand-written subscriptions had in fact been CPA, which was then transformed into standard Syriac by the compiler, or the scribe, of the dossier?

We should keep this possibility in mind. But various items of evidence make it much more likely, as Hoyland 2010 suggests, that what we are seeing is the adoption in this area of Classical Syriac (both script and dialect), as being by now the appropriate medium, alongside Greek, for formal Christian (and specifically monophysite?) self-expression, or literary composition, or the copying of codices. We do not need to think of the movement of individual Edessenes to this area (though one subscription, no. 17, is in fact given by a monk from Edessa). The status acquired by Syriac in the sixth century offers a sufficient explanation. Furthermore, it is generally accepted that CPA was used only by Chalcedonians.

As regards scribal activity in Syriac, we have significant evidence in the form of Syriac codices which are recorded by their scribes as having been copied in this region. ${ }^{13}$ In brief, five relevant codices are known. As regards Arabia, BL Add. 17,176, of CE 532, is dated by 'the year 427 of the province of Bostra (Arabia)', while Add. 12,170, of CE 604, records that it was written near Bostra. As regards Phoenicia Libanensis, BL Add. 12,135, was written at Hina (some $40 \mathrm{~km} \mathrm{SW}$ of Damascus) in CE 611, while two others refer explicitly to Damascus: the scribe of BL Add. 17,119, of the later sixth or early seventh century, records that the codex belonged to the convent of Silvanus in the territory of Damascus; while Wolfenbüttel 3.1.308, of CE 633, is stated to have been composed

${ }^{12}$ Compare the maps in Hoyland 2009, p. 123, and Hoyland 2010, p. 38.

${ }^{13}$ See the invaluable list in Hoyland 2009, p. 130. 
at the monastery of Beth Hala, 'which is in the region (KWR') of Damascus'. This colophon, in 70 lines of 2-4 words each, set out in a cruciform pattern, would deserve further study.

This evidence thus opens up the possibility that even in this relatively remote inland zone, Syriac had become established as the language and script which it was appropriate to use for the expression of Christian belief - or, to be more precise, for copying translations of Christian works (for all the five codices mentioned in fact contain translations from Greek, and none contains any works originally written in Syriac). What is significant however is scribal activity in Syriac, conducted in the rural monasteries of this area. Such a scribal culture need have no implications for the language, or languages, current among the surrounding population. It should be noted also that no public inscriptions in Syriac have been recorded from southern Libanensis or Arabia.

\section{A CODEX FROM NEAR PALMYRA}

Another Syriac codex, however, also listed by Hoyland 2009, is of still wider significance, and it is the chief purpose of this paper to explore it. This is BL Add. 14,559 (W. Wright, Catalogue II, pp. 4689, no. DLXXXV), similarly containing a Syriac translation of John Chrysostom's homilies on the Gospel of Matthew, and written 'in a good regular Estrangela hand of the VI ${ }^{\text {th }}$ cent.' (Wright). The main text has never been printed, but the Syriac colophon is quoted in full by Wright, and his text (fol. 107b) is reproduced here, followed by a translation (so far as is known, the first complete version in any modern language; I am very grateful to David Taylor for his corrections of my draft):

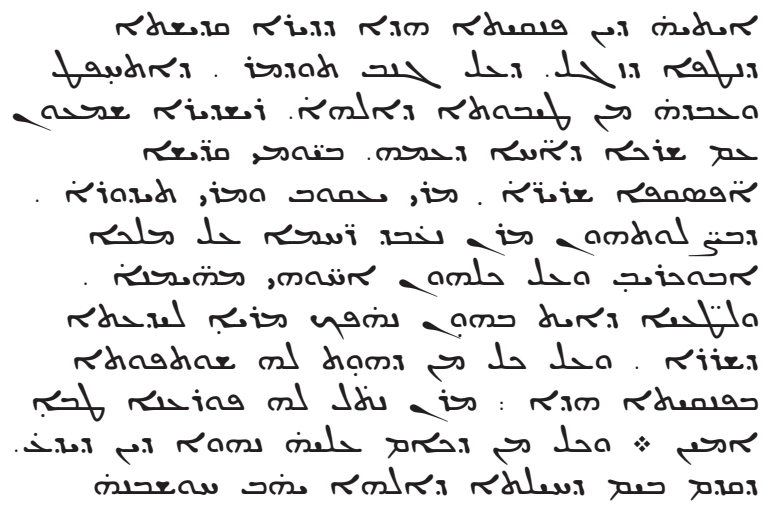




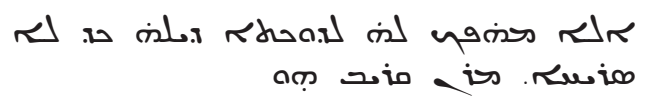

This book (PNQYT' - pinax) belongs to the holy monastery of NTP' DZGL which is near TWDMR (Palmyra). By the grace of God the Archimandrite (RYŠDYR') Symeon took pains and made it, along with the remainder of the Brothers who are with him, in the days of the holy and devout bishops, Mar Jacob and Mar Theodore, so that by their prayers Our Lord might show his compassion to King Abokarib (MLK' 'BWKRYB) and to all their Christian brothers, and that as regards their errors the Lord might lead them back to true knowledge. And as for anyone who participated in (the writing of) this book, may our Lord grant him a precious recompense. Amen. And that whoever hides it away, let him know that before the fearsome judgmentseat of God he will give a reckoning for it, unless he returns it to its place unharmed. Our Lord is near.

If the precise location of NTTP' DZGL (not otherwise attested) remains indeterminate, the reference to the vicinity of Palmyra is explicit, and the chronological and historical context is also clear, and, very significant. Both Nöldeke and Hoyland suggest convincingly that 'the holy and devout bishops, Mar Jacob and Mar Theodore' will be the two effective founders of the 'monophysite' (or later Syrian Orthodox) Church as a separate hierarchy: Jacob 'Baradaeus', nominally bishop of Edessa, and Theodore, whose notional see is recorded as either Bostra or as the camp of the Saracens' (HYRT' DTTYY'), as in John of Ephesus. ${ }^{14}$ Both were consecrated in CE 542/3, and proceeded to the ordination of large numbers of 'orthodox' clergy; it was only later, about 553, that their consecrations of bishops began. But, even in the period up to 566, the 27 bishops (along with two patriarchs) known to have been consecrated did not include one for Palmyra. ${ }^{15}$ That would therefore explain perfectly why, at the point where we would normally expect the scribe to name the bishop of the city in whose territory his monastery lay, he instead mentions these two itinerant,

14 Nöldeke 1887, p. 26; Hoyland 2009, p. 130. See John of Ephesus, Lives of the Eastern Saints 50 (ed. and trans. E.W. Brooks, PO XIX.2, p. 1534).

${ }^{15}$ Honigmann 1951, p. 178f. See also Fedalto II, 1988, p. 742. 
or missionary, bishops. The date could be any time up to CE 578, when Jacob Baradaeus died.

If this hypothesis is correct, it naturally follows that we are talking of a monophysite monastery situated in the far north of Phoenicia Libanensis, comparable to the large group attested in Arabia and southern Libanensis. Here too, it can be taken as probable that the use of Syriac was an importation derived from its now established status as a Christian language of culture, and hence that it does not tell us anything about linguistic usage in ordinary life in this area. It is indeed paradoxical that Palmyra, the home of by far the best-attested and most long-lasting bi-lingual corpus of inscriptions from the Near East, written in the local dialect of Aramaic and in Greek, should have abandoned the public use of Palmyrene abruptly in the 270s. What type of Aramaic dialect or script, if any, remained in use either in speech or for perishable documents in the fourth-sixth centuries is not known. As Prof. Michal Gawlilowski (Warsaw) has kindly confirmed, there are no Syriac inscriptions of this period from the Palmyrene area; but there is one quite extensive one, of 16 lines, from an unidentified locality situated on the Gebel Bil'as, some $75 \mathrm{~km} \mathrm{NW}$ of Palmyra and possibly within its territory. It refers to an Archimandrite (RŠDYR') whose name is missing, and dates to CE 574/5.16

Isolated as this Syriac codex thus is, the reference in the colophon to 'king' Abokarib again fits perfectly well into a midsixth century context. The well-known Sabaean inscription of CE 548 (CIS IV.2, no. 541) mentions embassies to the Christian king of Himyar, Abraha, from both 'Harith son of Gabalas' and 'Abkarib son of Gabalas'. It is a natural, if not absolutely certain, deduction that they were brothers, in other words that the same father is referred to in both cases.

Arethas, or al-Harith ibn Jabalah, is the well-known 'Arab' phylarchos, or king, of this period, attested in inscriptions, in both Greek and Old Arabic, in narrative sources in both Greek and Syriac, and in ecclesiastical correspondence, preserved in Syriac (the same collection of monophysite documents to which the letter of CE 569/70 belongs, see above). ${ }^{17} \mathrm{He}$ was also the earliest 'Arab' ally of Rome to be firmly attested as a monophysite: for it was 'the

16 Mouterde 1942/3.

17 The evidence is collected in PLRE IIIA, pp. 111-113, and discussed in Millar 2010, p. 210-213. See also Fisher 2011, esp. pp. 57-59. 
glorious Hereth bar Gabala, the great king (MLK') of the TYY' ', who, as John of Ephesus (trans. E.W. Brooks) records, made the crucial request in $542 / 3$ for the ordination of monophysite clergy. $\mathrm{He}$ is attested as ruling from the later 520 s to $569 / 70$. A significant testimony to his regional prominence is provided by two of the Greek inscriptions from Qasr al-Hayr al Gharbi, mentioned above.

Abokarib (or Abocharabus/Abū Karib, so PLRE IIIA, p. 3) is also attested as a phylarchos: by Procopius, referring to an area in the northern Hedjaz; in an recently published Greek papyrus from Petra; and in a Greek inscription from near Soueida in the north of the province of Arabia. ${ }^{18}$ It is noteworthy, therefore, that the allusion to him as 'king' in the colophon of the codex is the only known documentation of him in Syriac, and comes, as we have seen, from a monophysite context. It must tend to confirm that, like his brother Arethas, and later his nephew Mundhir

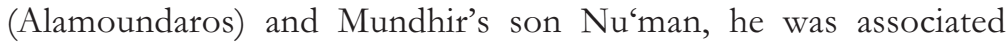
with the monophysite church. Or does the reference in the colophon to 'errors' imply that his commitment was less firm than theirs?

It is not surprising that another local reflection of Abokarib's role should be available to match the papyrus from Petra and the Greek inscription from near Soueida. Similar items of local documentation reflecting the prominent regional role of his brother Arethas come, as we have seen, from Qasr al-Hayr al Gharbi, and from the Jebel Seys east of Damascus, while those of Arethas' son Mundhir/Alamoundaros stretch more widely, from Resafa/ Sergiopolis in Euphratensis, to the area of Dumayr, east of Damascus, to the northern Hauran, and to a place identified as 'WQBT' in Arabia, in the form of the allusion, in subscription 121 of the letter of CE 569/70, to a presbyter of 'the church of the glorious and Christ-loving patrikios Mundhir' (MWNDR) which was situated there. Moreover, a Greek mosaic inscription from Tall al-'Umayri, $11 \mathrm{~km}$ south of Amman, recently revealed by the excavation of a church there, refers to 'Almoundaros'. ${ }^{19}$

18 See Millar 2010, p. 213-214, written in regrettable unawareness of the Syriac codex, discussed by Shahîd 2002, I.2, p. 845-850.

${ }^{19}$ For the papyrus see Arjava, et al. (2011), n. 39 (II. 165; 488); for the inscription, see al-Shami 2010 (in Arabic). I am very grateful to Greg Fisher for drawing this report to my attention and providing a translation of it. 
The reference to a church 'of' Mundhir is sometimes taken as evidence for active euergetism by him, as practised in the main base of the 'Ghassanids' or 'Jafnids' in Roman Arabia, and of course this may well have been the case. But we should note the parallel provided by the Syriac Life of Ahudemmeh, who, in the sixth and seventh decades of the sixth century, was active in the monophysite cause within the Sasanid empire, and particularly in the conversion of the Tayyoye. His anonymous biographer records that he 'founded churches and named them after the chiefs of their tribes in order that they might help them (the churches) in any matter in which they were in need'. ${ }^{20}$ So the allusion to 'his' church is certainly evidence both for the regional prominence of Mundhir and for his monophysite commitment; but it is not secure proof of any initiative by him in either arranging or financing its construction.

As regards the role of Abokarib, Procopius ascribes to him a territory, 'the Palm Grove (Phoenikon)', evidently situated beyond the southern borders of Roman control in north-west Arabia, of which he made a gift to Justinian; and he also records that Justinian made him phylarchos of the Saracens in Palestine. ${ }^{21}$ This testimony fits with the fact that Petra, the location of the Greek papyrus alluding to him, was the metropolis of Palaestina III. So it may seem surprising that the scribe of this codex, copied far to the north, in the area of Palmyra, chooses to refer to the 'king' Abokarib, rather than to his brother. But it should be stressed, first, that neither these local reflections of the prominence of members of this family nor the narrative accounts of them, above all by Procopius and John of Ephesus (many of which involve their military role in conflicts with Sasanid Persia), provide clear evidence of a strict territorial demarcation of their respective roles (or those of other contemporary 'Arab' phylarchs who are attested in the same general area, see below); or provide an adequate basis for an account of their civil or military power; or justify any presumption

${ }^{20}$ The text is edited and translated by Nau 1909, ch. 4 (p. 27); see also Segal 1984, 119.

21 Procopius, Hist. 1.19.7-14. Procopius' account of the location of Phoenikon is vague, since he says both that it was immediately beyond the borders of Palaestina (III) and that it could be reached only by a ten-day journey through barren land. 
that they had replaced the local governmental and military structures of the Empire in this area.

\section{A ‘GHASSANID’ DyNASTY?}

The dangers of over-interpretation, of constructing a picture of an established regional power, are greatly increased by the tendency to label the entire dynasty as 'Ghassan'. ${ }^{22}$ But no contemporary source in Greek, Syriac, Sabaean or Old Arabic applies this or any other collective term to these persons, whether as a single family, or as deriving from a wider descent-group, or as belonging to a 'clan' or a 'tribe'. Our contemporary evidence never uses any ethnic labels for them which are more specific than 'Saracens' in Greek or 'Tayyoye' in Syriac; and, insofar as it records family relationships at all, speaks only of Arethas (and also Abokarib) as the son of Gabalas, Mundhir as the son of Arethas and Nu' man as the son of Mundhir. These points are very clearly set out in the recentlypublished book by Greg Fisher (2011) on the role of 'Arab' dynasties operating between the Roman and Sasanian empires. ${ }^{23}$

Whether the collective designation 'Ghassan' can properly be used is therefore, in the first instance, a problem in early Islamic historiography, as regards which the reconstruction offered in the classic paper by Theodor Nöldeke remains fundamental. ${ }^{24}$ But until the literary character and evidential bases of the post-Islamic narratives relating to the pre-Islamic period have been subject to detailed re-evaluation, the question of whether we should speak of an established 'Ghassanid' regime must remain open.

I have already stressed the need for such a revaluation elsewhere. ${ }^{25}$ Since then, however, a highly significant reexamination of one item of source-material has taken place, which is extremely relevant to the question of 'Ghassan', and of whether

${ }^{22}$ Here I take a different view from that expressed in Hoyland 2009, esp. p. 118-120.

${ }^{23}$ See Fisher 2011, esp. p. 3f., for the argument that the connection between empires and peripheral groups will normally, as they are in this case also, be expressed in terms of relations with prominent individuals, or dynasties, not with peoples, or 'tribes'. In any case almost nothing is known about what sort of group 'Ghassan' may have been, or where they were located in this period.

${ }^{24}$ Nöldeke 1887.

${ }^{25}$ Millar 2010, p. 220-221. 
we have contemporary evidence of a 'Ghassanid' base, or camp, established in the sixth century at a named location, apparently in the province of Arabia.

This evidence comes in a note at the end of a Syriac letter, known from a twelfth-century manuscript, giving a detailed account of the already well-attested martyrdoms of Christians in the 520s at Najran in Himyar (Yemen). This letter was first published by Irfan Shahîd in 1971, who took it to be the work of a well-known contemporary, Simeon of Beth Arsham (see below). If this is indeed a contemporary document, or even one closely based on contemporary material, then we do have concrete evidence for Gabalas (the father of Arethas) as king of Ghassan, and for the location of his 'camp'. The beginning of the letter is lost, along with any reference to the identity of the writer. But the terminal note is preserved, and runs as follows: ${ }^{26}$

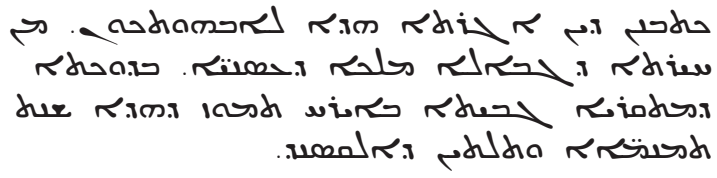

Shahîd offers the following translation, which is also in reality a commentary or explication (p. 63):

We have written this letter to you, your Fathership, from the camp of GBÂLÂ 〈Jabalas, king of the 'SNYA «Ghassânids», at the place called GBYTÂ «al-Jâbiya), in the month Tammûz July' of this year, eight hundred and thirty of ALQSNDR «Alexander).

It must be preferable, in the author's view, to keep to the bare text of the original:

We have written this letter to your Fatherhood from the camp of Gabala, King of the 'SNYA', in the place called GBYT', in the month Tammuz of this the $830^{\text {th }}$ year of Alexander.

Before we assess any of the details provided by this text, we need to take account of the excellent recent study by David Taylor analysing the literary character and authorship of the various Syriac narrative sources on the martyrdoms at Najran. ${ }^{27}$ His conclusions,

26 Shahîd 1971. For the Syriac text of the note see p. xxxi, 1l. 21-24.

27 Taylor 2010. 
to summarise drastically, are (1) that the best-established source for these events is the letter of Simeon of Beth Arsham which is quoted in Pseudo-Zachariah, Ecclesiastical History VIII. $3,{ }^{28}$ and of which versions are also reproduced in the eighth-century Chronicle of Zuqnin, in Michael the Syrian, and in a Syriac codex, BL Add. 14,641, of which the relevant part was copied in the tenth or eleventh century; (2) that other narratives, such as the Syriac letter published by Guidi, or the 'Book of the Himyarites', or the letter published by Shahîd, should not be presumed to be authentic sources of extra information, but should rather be understood as later literary elaborations on a dramatic and familiar story; and (3) that this last letter was not written by Simeon of Beth Arsham. It does not follow, of course, that it contains no authentic material. But it does follow that it cannot, at least for the moment, be regarded as providing independent historical evidence. By contrast, the fact that the Ecclesiastical History of Ps.-Zachariah was not only written in the second half of the sixth century, but is found in a manuscript of the late sixth or early seventh century, while the new letter published by Shahîd comes from one of the twelfth century, is also very relevant. In view of complexities of the tradition, it is necessary to set out the heading and the beginning of the address of the letter of Simeon as found in Ps.-Zachariah (trans. Greatrex, Phenix and Horn):

The third chapter of the same book gives information concerning the martyrs who were killed in Najran, the royal city of the Himyarites, in the year 835 of the Greeks, being the sixth year of Justin's reign [CE 523/4], as Simeon the bishop and apocrisiarius of the faithful from the land of the Persians wrote to Simeon, the abbot of Gabbula, as follows: We inform Your Charity that on the twentieth of January of this year, 835 of the Greeks, we went out from Hirta de-Nu'man with the priest Abraham the son of Euphrasius, who was sent by emperor Justin to Mundhir to conclude peace...

In this context therefore, the fact that the letter published by Shahîd dates the events concerned five years earlier than Simeon does is problematic in itself. Similarly, Simeon's letter, as quoted by

28 See now the invaluable Introduction, Translation and Commentary by Greatrex, Phenix and Horn 2011. 
Ps-Zachariah later in the sixth century, derives from a well-attested context, namely embassies to Hirta de-Nu'man, the camp of the 'Lakhmid' Mundhir, in the mid-520s, and refers to communications reaching him there from Himyar. But, by contrast, no context is provided for the sudden appearance at the end of the letter published by Shahîd of the note, quoted above, saying that it had been written at the camp of Gabala at Gabitha. What is evidently this same place is indeed attested, half a century later than the context represented in the letter, in the 24th of the 137 subscriptions of 569/70 (see above): 'presbyter and head of monastery of Beth Mar Sergius of GBYT' '. It is very relevant that 'the church of Mar Sergius at Gabitha' is also independently attested in a letter of Peter of Callinicum quoted by Michael the Syrian (X.22): 'urged by us and by the glorious phylarch they met with us for the second time in the church of Mar Sergius at Gabitha'. The broad geographical context is thus clear, as is the influence of the phylarch (whether Arethas or his son Mundhir is uncertain). But in these two sixth-century documents Gabitha is identified as the site of a church of Mar Sergius, and (very significantly) not as the 'camp' of a 'Ghassanid' phylarch. No such 'camp' is identified in any pre-Islamic sources, and when later Islamic writers refer to it the place-name which they give to it is (as in the quotation from Shahîd, above) 'al-Jâbiya' or 'Khirbet al Jābiya' (so Hoyland 2010, p. 135). As Robert Hoyland assures me, 'Jabiya' in Arabic is the natural transliteration of 'Gabitha' in Syriac. So it would be perverse not to identify this as the same place. ${ }^{29} \mathrm{But}$ we still lack any provably pre-Islamic evidence for the establishment of a 'Ghassanid' base, or camp, there.

Similarly, what evidence entitles us to give this four-generation dynasty of 'kings' or 'phylarchs' the collective designation 'Ghassanids' (or, as some prefer, 'Jafnids')? The question of the status of the note at the end of the new Syriac letter is vital. The anonymous author says that he is writing 'from the camp (HYRT') of Gabala, king of the 'SNY' '. Shahîd's informative note on this word deserves to be quoted in full (Shahîd 1971, p. 109):

1.43: حمبن, "Ghassanids" a most precious word, a hapax legomenon in the Syriac sources which do not refer

29 See Nöldeke 1875, p. 430; Dussaud 1903, p. 45-7; Dussaud 1927, p. 332-3; Shahîd 2002, p. 96-104; Hoyland 2011, p. 135. 
to the Ghassânids of pre-Islamic times as riven, their well-known name in Arabic. The Syriac writer formed the word from "Ghassân", by pluralizing its relative adjective. The initial consonant in Arabic is ghayn, usually transliterated into Syriac by a gâmal with a diacritical dot, but the writer has chosen to transliterate it by a 'ayn with a diacritical dot.

The fact that there are no known pre-Islamic references to 'Ghassan' in Syriac texts is telling (though we should note that a closely similar term, 'YSNY', but in the singular, and evidently a place-name, appears in subscription no. 129 of the letter of 569/70); and it is also telling that the form of transcription used here (in a manuscript of the twelfth century) was borrowed from Arabic pronunciation. It thus seems quite possible that the reference to Gabala(s), Ghassan and Gabitha is a late invention, designed to lend the letter a note of concreteness and plausibility, perhaps prompted by the reference to the camp (HYRT') of the 'Lakhmid' Nu'man in the letter of Simeon of Beth Arsham as quoted by Pseudo-Zachariah (see above).

We thus arrive, not at a provably negative conclusion, but at a quandary. If this evidence is valid, it demonstrates that the earliest known member of this dynasty, Gabalas, first attested in 497/8 as mounting an attack on Roman Palestine, ${ }^{30}$ was still in power, and was identified as 'king of Ghassan', and also as having his camp at Gabitha, somewhere in the province of Arabia, in CE 519. But the literary character of the text, the date of the manuscript itself, the dating given in it, which contradicts the evidence of our best source, and the term used to identify Gabala's subjects all give rise to serious doubts. Further research is required before the military, political, ethnic, religious and linguistic history of these frontier provinces of the Empire in the sixth century, Phoenicia Libanensis, Arabia and Palaestina III, can be written. If the proposition that the expression 'the power of Ghassan' (Hoyland 2011) can validly be used to characterise the political or military structure of these areas in the sixth century is to be supported, the first step would be a detailed treatment of the post-Islamic sources which tell the story of the 'Ghassanids' or 'Jafnids' of the sixth century, preferably in

30 Theophanes, Chronographia, ann. 5990, see Mango and Scott 1997, p. 216-217. 
the form of critical editions of the relevant texts, a discussion of the source-material used by them, detailed notes, and a translation.

Even if it then appeared that these texts were well-informed about the sixth-century situation, we would still have to take into account the fact that contemporary sources demonstrate that there were other 'Saracen' or 'Arab' phylarchs operating in the same area at the same time, whom we have no reason to identify as 'Ghassanid' or 'Jafnid'. One of them indeed is quite clearly associated with a different four-generation family of Saracen phylarchs. This is the Terebon, 'the famous phylarch of the Saracens in this area', who was an informant of Cyril of Scythopolis in the $540 \mathrm{~s}$ or $550 \mathrm{~s}$, and who was clearly the grandson of the Terebon who was the son of the phylarch Aspebetos, who had converted to Christianity in the 420s (Cyril of Scythopolis, Life of

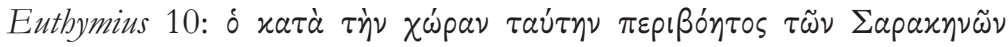

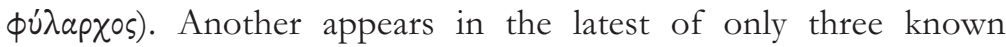
inscriptions from the sixth century which are written both in Old Arabic and in Arabic script: in this case the document is in Greek and Arabic, and records the foundation of a martyrion in CE 568. It comes from Harran in Roman Arabia, precisely in the region of presumed 'Ghassanid' dominance (Millar 2010, p. 219). But the phylarch named is called 'Sharahi, son of Zalim', and there is no basis for associating him with that dynasty. One of the other two Arabic inscriptions, from Jebel Seys, does record Arethas as 'king', in CE 528/9; but the earliest of them, from CE 511/12, in which the Arabic text is attached to a bilingual record, in Greek and Syriac, of (once again) the foundation of a martyrion, comes from far to the north, at Zebed near Chalcis, and makes no reference to any phylarch. ${ }^{31}$ It is of course very significant that Arabic does appear, if rarely, in the Roman Near East of the sixth century - but there is no sufficient reason to attribute whatever currency it enjoyed to the power or influence of any one dynasty of 'Arab' phylarchs.

31 For an excellent treatment of these documents see Fisher 2011, 144-153.

I am very grateful for information, advice and assistance to Michal Gawlikowski, Robert Hoyland, Meredith Riedel and David Taylor. 


\section{CONCLUSION}

So, as regards the future exploration of this topic, much will depend on the detailed critical examination of the available postIslamic Arabic sources. But whatever view of them comes to be taken, it would be very remarkable if they were to be accepted as providing a valid historical framework, into which the contemporary documentary and literary evidence should be fitted. For the moment at least, the contrary procedure is the only one which is methodologically valid, namely that that interpretation of later narratives must be based primarily on the contemporary documentation. And in this context, while a Syriac translation from the works of Chrysostom is in itself a historical datum of some importance, the particular copy of it made in a monastery near Palmyra in the middle of the sixth century has the status of a major contemporary document. This is, firstly, because this is the only evidence to date for scribal activity in Syriac in this relatively remote inland region, between the Euphrates to the east, the Orontes valley to the west and the Damascus area to the south. Second, there is the reference in the colophon to bishops Jacob and Theodore, the effective founders of a separate monophysite church; and, third, the allusion to 'King' Abokarib. His regional prominence is thus attested. But it is less clear whether he showed the deep attachment to the monophysite cause which was shown by his brother Arethas, his nephew Mundhir (Alamoundaros) or his great-nephew $\mathrm{Nu}^{\prime}$ man. None the less, this brief colophon casts new light on the political, religious and linguistic history of the Near East in the middle of the sixth century.

\section{BIBLIOGRAPHY}

Al-shami, A.J. (2010): 'Archaeological Excavations at Tall al-'Umayri, 2009 Season', AD AJ 54 (Arabic section), p. 35-42.

Arjava, A., Buchholz, M., Gagos, T., Kaimo, M. (2001), The Petra Papyri IV, Amman, American Centre of Oriental Research.

Barag, D. 2010: 'Samaritan Writing and Writings', in Cotton et al. (eds.), p. 303-323.

Briquel Chatonnet, F., Debié, M., Desreumaux, A. 2004: Les inscriptions syriaques, Paris, Librairie Orientaliste Paul Geuthner.

Briquel Chatonnet, F., Desreumaux, A. 2011a: 'Syriac Inscriptions in Syria', Hugoye 14, p. 27-44. 
Briquel Chatonnet, F., Desreumaux, A. 2011b: 'Oldest Syriac Inscription discovered in North Syria', Hugoye 14.1, p. 45-61.

Brock, Sebastian 2009: 'Edessene Syriac inscriptions in late antique Syria', in Cotton et al. (eds.), p. 289-302.

Chabot, J-B. 1907 and 1933: Documenta ad Origines Monophysitarum Illustrandas, CSCO, Scriptores Syri, ser. 2, XXVII and LII (Latin translation).

Cotton, H.M., Hoyland, R.G., Price, J.J., Wasserstein, D.J. 2009: From Hellenism to Islam: Cultural and Linguistic Change in the Roman Near East, Cambridge, Cambridge U.P.

Dussaud, R. 1903: Mission dans les régions désertiques de la Syrie moyenne, Paris, Imprimerie Nationale.

Fedalto, G. 1988: Hierarchia Ecclesiastica Orientalis II, Padua, Edizioni Messagero.

Fisher, G. 2011: Between Empires: Arabs, Romans and Sasanians in Late Antiquity, Oxford. Oxford University Press.

Genequand, D. 2006: 'Some Thoughts on Qasr al-Hayr al Gharbi, its Dam, its Monastery and the Ghassanids', Levant 38, p. 63-84.

Greatrex, G., Phenix, R., and Horn, C. 2011: The Chronicle of PsendoZachariah Rhetor: Church and $W$ ar in Late Antiquity (Translated Texts for Historians 55), Liverpool, Liverpool U.P.

Honigmann, E. 1951: Évèques et évêchés monophysites d'Asie antérieure au VI siècle, Louvain, Imprimerie Orientaliste.

Hoyland, Robert 2009: 'Late Roman Provincia Arabia, Monks and Arab Tribes: A Problem of Centre and Periphery', Semitica et Classica 2, p. 117-139.

Hoyland, Robert 2010: 'Mount Nebo, Jabal Ramm, and the Status of Christian Palestinian Aramaic and Old Arabic in Late Roman Palestine and Arabia', in M.C.A. Macdonald (ed.), The Development of Arabic as a Written Language (Supp. to Proceedings of the Seminar for Arabian Studies, 40), Oxford, Archeopress, p. 29-46.

Mango, C. and Scott, R. 1997: The Chronicle of Theophanes Confessor, Oxford, Oxford University Press.

Millar, Fergus 2009a: 'The Syriac Acts of the Second Council of Ephesus (449)', in Price, R. and Whitby, M. (eds.), Chalcedon in Context: Church Councils 400-700, Liverpool, Liverpool U.P., p. 45-69.

Millar, Fergus 2009b: 'Christian Monasticism in Roman Arabia at the Birth of Mahomet', Semitica et Classica 2, p. 97-115.

Millar, Fergus 2010: 'Rome's >Arab Allies in Late Antiquity. Conceptions and Representations from within the Frontiers of the Empire', in H. Börm and J. Wiesehöfer (eds.), Commutatio et Contentio: Studies in the Late Roman, Sasanian, and Early Islamic Near East. In Memory of Zeev Rubin, Düsseldorf, Wellem Verlag, p. 199-226. 
Mouterde, R. 1942/3: 'Inscription Syriaque du Gebel Bil'ās', MUSJ 25, p. 93-86.

Mundell Mango, M. 1991: 'The Production of Syriac Manuscripts 400-700 AD', in Cavallo, G., De Gregorio, G. and Maniaci, M., Scritture, libri e testi nelle aree provinciale di Bisanzio, Spoleto, Centro Italiano di Studi sull'Alto Medioevo, p. 161-179.

Nau, F. 1909: Histoire de Saint Mar Aboudemmeh, PO III.1, p. 15-51.

Nöldeke, Th. 1875: 'Zur Topographie und Geschichte des Damascenischen Gebietes und der Hauran', ZDMG 29, p. 419-443.

Nöldeke, Th. 1887: Die Ghassânischen Fürsten aus dem Hause Gafna, Berlin, König. Ak. d. Wiss.

Prosopography of the Later Roman Empire (PLRE) IIIA, Cambridge, Cambridge University Press, 1992.

Segal, J.B. 1984: 'Arabs in Syriac Literature before the Rise of Islam', Jerusalem Studies in Arabic and Islam 4, p. 89-124.

Shahîd, Irfan 1971: The Martyrs of Najrân: New Documents, Brussels, Société des Bollandistes.

Shahîd, Irfan 2002: Byzantium and the Arabs in the Sixth Century I-II, Washington D.C., Dumbarton Oaks.

Taylor, David G.K. 2010: 'A Stylistic Comparison of the Syriac Himyarite martyr texts attributed to Simeon of Beth Arsham', in J. Beaucamp, F. Briquel Chatonnet and C.J. Robin (eds.), Juifs et Chrétiens en Arabie aux $V^{t}$ et $V I^{e}$ siècles: Regards croisés sur les sources, Paris, Ass. Am. d'hist. et civ. Byz., p. 143-176.

van Roey, A. and Allen, P. 1994: Monophysite Texts of the Sixth Century, Leuven, Peeters.

Wright, W. 1870-2: Catalogue of Syriac Manuscripts in the British Museum I-III, London, British Museum (repr. 2002, Piscataway N.J., Gorgias Press). 
